\title{
The gene expression analysis of Arabidopsis thaliana $A B C$ transporters by real-time PCR for screening monolignol-transporter candidates
}

\author{
Manami Takeuchi ${ }^{1} \cdot$ Atsushi Watanabe $^{2} \cdot$ Miho Tamura $^{2} \cdot$ Yuji Tsutsumi $^{2}$
}

Received: 25 December 2017 / Accepted: 7 May 2018 / Published online: 1 June 2018

(C) The Japan Wood Research Society 2018

\begin{abstract}
The transport of monolignols from the cytosol to the cell wall is essential for lignin synthesis. The ATP-binding cassette (ABC) transporters may be involved in the transport of lignin precursors. ABC transporter genes subjected to expression analysis were chosen based on two criteria for screening candidate transporter genes related to lignification. The expression levels of 15 target genes in five plant organs were analyzed by real-time PCR. Five transporter genes ( $A B C G 29, A B C G 30$, $A B C G 33, A B C G 34$, and $A B C G 37$ ), which were simultaneously expressed with the reference genes, were selected as candidates. The candidate gene expression levels in root tissues of T-DNA insertion mutants were determined by semi-quantitative reverse transcription PCR. ABCG30 was more highly expressed in the abcg34 mutant than in the wild-type plants, while the expression of $A B C G 34$ was twofold higher in the abcg30 mutant plants than in the wild-type plants. Thus, the expression of $A B C G 30$ and $A B C G 34$ may affect each other. There was no significant change in lignin content and composition in the single-gene knockout mutants of the candidate transporter genes, which suggested that each candidate gene did not solely contribute to lignin synthesis.
\end{abstract}

Keywords Arabidopsis thaliana $\cdot$ ATP-binding cassette transporter $\cdot$ Lignification $\cdot$ Gene expression $\cdot$ Knockout mutant

\section{Introduction}

Lignin deposits in the cell wall of plants and is important for conducting water and providing structural support. Lignin synthesis involves monolignol synthesis, extracellular transport, and oxidative coupling. Monolignol synthesis occurs in the cytosol, while oxidative coupling takes place in the extracellular space. The transport of monolignols to the outside of the cell is an essential process. To date, several studies have revealed part of the lignin synthesis mechanism. However, the mechanism underlying the extracellular monolignol transport remains relatively uncharacterized.

\section{Electronic supplementary material The online version of this} article (https://doi.org/10.1007/s10086-018-1733-9) contains supplementary material, which is available to authorized users.

Yuji Tsutsumi

y-tsutsu@agr.kyushu-u.ac.jp

1 Department of Agro-environmental Sciences, Graduate School of Agriculture, Kyushu University, 6-10-1 Hakozaki, Higashi-ku, Fukuoka 812-8581, Japan

2 Faculty of Agriculture, Kyushu University, 6-10-1 Hakozaki, Higashi-ku, Fukuoka 812-8581, Japan
Studies have attempted to screen for transporters related to extracellular monolignol transport. Investigations of gene expression patterns in stem during different growth stages of Arabidopsis thaliana using microarray analyses detected genes encoding ATP-binding cassette (ABC) transporters, which were synchronously expressed with phenylpropanoid synthesis genes [1]. Plasma and vacuolar membrane vesicles prepared from $A$. thaliana leaf cells selectively transport monolignols and monolignol glucosides, respectively, in the presence of ATP. Thus, ABC transporters may be involved in monolignol transport [2]. Several ABC transporters described in a study by Ehlting et al. [1] were functionally analyzed [3]. Loss-of-function mutants of selected ABC transporters exhibited no differences in lignin deposition compared with wild-type controls. A co-expression analysis involving microarray data revealed that $A B C G 29$, which is synchronously expressed with some phenylpropanoid synthesis genes, may encode a $p$-coumaryl alcohol transporter [4]. However, the transporters responsible for transferring two other kinds of monolignols (e.g., coniferyl and sinapyl alcohols) from the cytosol to the cell wall have not been identified. 
The $\mathrm{ABC}$ transporters form a large protein families and are present in all organisms, ranging from bacteria to higher organisms $[5,6]$. These transporters are characterized by their ability to transport diverse molecules across cell membranes using energy released from ATP hydrolysis. Specifically, terrestrial plants have more ABC transporter genes than any other organism, including higher animals [7]. The ABCG transporters represent the largest ABC transporter subfamily in A. thaliana, with 15 full-size and 28 half-size members [8]. Full-size ABCG transporters have been identified in plants, fungi, oomycetes, brown algae, and slime molds, but not in animals [9-11]. Plants are believed to have adapted to dry land by employing secondary metabolites. The multiplication and functional diversification of plant $\mathrm{ABC}$ transporters may have enabled the transport of secondary metabolites. In fact, some secondary metabolites may have been transported by $\mathrm{ABC}$ transporters, in particular ABCG subfamily members $[12,13]$. Moreover, almost all ABCG proteins studied to date localize to the plasma membrane. Additionally, ABCG29 is an ABCG full-size transporter [4]. It is highly likely that other monolignols that are included in lignin polymers are extracellularly transported by ABCG transporters.

In this study, the screening of candidates for monolignol transport was carried out by analyzing target genes selected based on two criteria. First, a lignified cell wall is a characteristic feature of vascular plants and may have been acquired during evolution. A. thaliana plants contain vascular bundles, and lignin comprises approximately $16 \%$ of the cell wall's dry weight. A. thaliana lignin mainly consists of coniferyl (guaiacyl type) and sinapyl (syringyl type) alcohols, as well as some $p$-coumaryl ( $p$-hydroxyphenyl type) alcohol [14]. In contrast, Physcomitrella patens, which is a non-vascular plant species, has a lignin-like polymer composed of a $p$-hydroxyphenyl-type monomer [15]. Thus, the genes responsible for guaiacyl- and syringyl-type monolignol transport may be conserved in A. thaliana but not in P. patens.

The second method for selecting target genes involved the tracheary element (TE) induction, in which the formation and lignification of the secondary wall are promoted shortly after an induction treatment. During the lignification process, lignification-related transporter genes may be expressed simultaneously with other lignification-related genes. In our earlier study, a gene expression analysis of TE-differentiated cultured cells revealed that four ABCG transporter genes were synchronously expressed with genes related to lignin synthesis and secondary wall formation, and one ABCG transporter gene was highly expressed during lignification [16]. These transporters are expected to be involved in monolignol transport.

In total, 15 transporters were further screened by comparing the expression profiles of the corresponding genes with those of reference genes in five plant organs at two growth stages that differed regarding lignification levels. Five transporters were subsequently selected as plausible monolignol-transporter candidates. The analyses of candidate gene expression levels in the single-knockout mutants were conducted based on semi-quantitative reverse transcription PCR. We then measured the lignin content, as well as the syringyl/guaiacyl (S/G) and $p$-hydroxyphenyl/guaiacyl $(\mathrm{H} / \mathrm{G})$ ratios, in single-knockout mutants of the five screened genes to functionally characterize the candidate genes.

\section{Materials and methods}

\section{Plant materials and growth conditions}

Seeds of A. thaliana were surface sterilized using $0.5 \%$ hypochlorous acid and then washed four times with distilled water. Seeds were added to plates containing full-strength Murashige and Skoog medium supplemented with 3\% sucrose. The plates were incubated at $4{ }^{\circ} \mathrm{C}$ in darkness for 2 days, and moved to $22^{\circ} \mathrm{C}$ under a 16 -h light/8-h dark cycle (light intensity of $54 \mathrm{~mol} \mathrm{~m}^{-2} \mathrm{~s}^{-1}$ ). Plants were transferred to soil 3 weeks after germination and incubated for specific periods under the aforementioned growth conditions.

\section{Gene expression analysis among plant organs at different growth stages}

Total RNA was isolated from five plant organs: upper stem ( $2 \mathrm{~cm}$ length from the top), cauline leaf, rosette leaf, basal stem ( $2 \mathrm{~cm}$ length from the bottom), and root (whole root) in 4- and 6-week-old A. thaliana using the FavorPrep ${ }^{\mathrm{TM}}$ Plant Total RNA Mini Kit (Favorgen Biotech Corp., Ping-Tung, Taiwan). The RNA was treated with Recombinant DNase I (Toyobo Co., Osaka, Japan). First-strand cDNA was synthesized from 100 ng of RNA using a ReverTra Ace ${ }^{\circledR}$ (Toyobo Co.) with a mixture of oligo (dT) and random primers. The cDNA solution was diluted 10 times with ultra-pure water (Merck Millipore, Darmstadt, Germany) and used as template. Online Resources 1 and 2 list the primer sequences for the $\mathrm{ABC}$ transporter and reference genes, respectively. The copy numbers of the fragments for each target gene were estimated using a standard-curve method. Each fragment was amplified using the KOD-Plus-Neo (Toyobo Co.). The PCR products were purified with LaboPass ${ }^{\mathrm{TM}}$ GEL (Hokkaido System Science Co., Ltd., Sapporo, Japan). The initial copy numbers of purified fragments were estimated using nucleic acid concentrations measured with a NanoDrop 2000 (Thermo Fisher Scientific Inc., Waltham, MS, USA). The qPCR analyses were carried out in an AriaMx Real-Time PCR (Agilent Technologies Inc., Santa Clara, CA, USA) programmed for: 1 cycle of $3 \mathrm{~min}$ at $95{ }^{\circ} \mathrm{C}$, followed by 
40 cycles each consisting of $5 \mathrm{~s}$ at $95{ }^{\circ} \mathrm{C}$ and $10 \mathrm{~s}$ at $60^{\circ} \mathrm{C}$. The reaction solutions contained $8 \%$ extracted cDNA after dilution (volume), $0.4 \mu \mathrm{M}$ forward and reverse primers, Brilliant III Ultra-Fast SYBR ${ }^{\circledR}$ Green QPCR Master Mix (Agilent Technologies Inc.), and ultra-pure water. To examine the specific amplifications of target genes, melting curves were obtained after the amplifications. The correlation coefficients of the standard curves in this experiment were high $\left(r^{2}>0.98\right)$. The relative quantity of target mRNA was normalized using the gene for an ubiquitin extension protein (At3g62250) as an internal standard. Raw scores for each gene were standardized to $z$-scores. A heat map was generated and hierarchical clustering was completed with the heatmap. 2 function of the gplots package using the R statistical analysis software (R. ver.3.4.3, R Core Team (2017), http://www.r-project.org).

\section{Selection of homozygous mutant}

All T-DNA insertion mutants were obtained from the Arabidopsis Biological Resource Center. The homozygous plants were screened with PCR, using gene specific primers (Online Resource 3) and a T-DNA-specific primer (LBb 1.3: ATTTTGCCGATTTCGGAAC).

\section{Semi-quantitative expression analysis of candidate genes in the single-knockout mutants}

Total RNA was extracted from the roots of 4-week-old plants with the FavorPrep ${ }^{\mathrm{TM}}$ Plant Total RNA Mini Kit and reverse-transcribed with the PrimeScript ${ }^{\mathrm{TM}}$ 1st strand cDNA Synthesis Kit (TaKaRa Bio, Otsu, Japan). The resulting firststrand cDNA samples were diluted twofold, after which 1- $\mu$ l aliquots were used as templates for a PCR amplification in a final volume of $25-\mu$ l containing TaKaRa Ex Taq (TaKaRa Bio) and gene-specific primers (Online Resource 4). The PCR program was as follows: $98{ }^{\circ} \mathrm{C}$ for $10 \mathrm{~s} ; 25$ cycles of $98^{\circ} \mathrm{C}$ for $10 \mathrm{~s}, 55^{\circ} \mathrm{C}$ (UBQ5, $A B C G 34$, and $\left.A B C G 37\right)$ or $60{ }^{\circ} \mathrm{C}$ ( $A B C G 29, A B C G 30$, and $\left.A B C G 33\right)$ for $30 \mathrm{~s}$, and $72{ }^{\circ} \mathrm{C}$ for $90 \mathrm{~s}$. The PCR products for the transporter genes and $U B Q 5$ were analyzed in 1 and $2 \%(\mathrm{w} / \mathrm{v})$ agarose gels, respectively, and stained with ethidium bromide.

\section{Lignin analysis}

The lignin content was determined according to the acetyl bromide method [17]. Briefly, 6-week-old A. thaliana stems were ground in liquid nitrogen and treated three times with methanol. Extract-free, oven-dried samples (approximately $10 \mathrm{mg}$ ) were digested with a $10-\mathrm{ml}$ acetic acid solution containing $25 \%$ acetyl bromide at $70{ }^{\circ} \mathrm{C}$ for $30 \mathrm{~min}$. After cooling, sample solutions were transferred to glass tubes containing $9 \mathrm{ml} 2 \mathrm{~N}$ sodium hydroxide and $20 \mathrm{ml}$ glacial acetic acid, after which $1 \mathrm{ml} 7.5 \mathrm{M}$ hydroxylamine hydrochloride was added. All solutions were added to a measuring flask and diluted to $50 \mathrm{ml}$ with glacial acetic acid. Solutions were homogenized and filtered through cotton. The resulting filtrate was spectrophotometrically analyzed at $280 \mathrm{~nm}$.

The lignin composition was determined according to the pyrolysis gas chromatography/mass spectrometry [18]. Briefly, inflorescence stems ( $2 \mathrm{~cm}$ length) from the base of 6-week-old plants were collected and treated twice with methanol. Approximately 0.1-mg air-dried samples were pyrolyzed in the presence of $2-\mu 125 \%$ tetramethylammonium hydroxide at $500{ }^{\circ} \mathrm{C}$ for $4 \mathrm{~s}$ using the JHP-5 Curiepoint Pyrolyzer (Japan Analytical Industry Co., Ltd., Tokyo, Japan). The volatile products were sent to the 7890A/5975C MSD gas chromatography/mass spectrometry system (Agilent Technologies, Inc.) through a transfer line heated to $250{ }^{\circ} \mathrm{C}$ and separated on a Quadrex 007-1 capillary column $(25 \mathrm{~m} \times 0.25 \mathrm{~mm} \times 0.25 \mu \mathrm{m})$. The column temperature was set at $50{ }^{\circ} \mathrm{C}$ for $1 \mathrm{~min}$ and then increased to $300{ }^{\circ} \mathrm{C}$ at $5{ }^{\circ} \mathrm{C} /$ min, after which it was maintained for $10 \mathrm{~min}$. The injection and detector were set at 250 and $280{ }^{\circ} \mathrm{C}$, respectively. The analyzed products are listed in Online Resource 5.

\section{Results and discussion}

\section{Selection of transporter genes for expression analyses}

The transporter genes analyzed by real-time PCR were selected in two ways. First, the A. thaliana genes encoding ABC transporters were compared with those of $P$. patens. An earlier investigation identified the $P$. patens ABC transporter genes having close A. thaliana homologs [19]. These A. thaliana ABC transporters were excluded from our study, because they were conserved in vascular and non-vascular plant species. The full-type ABCG subfamily members were selected as target transporters, because some were reported to contribute to the transport of secondary metabolites. We analyzed the expression levels of the following ten full-type A. thaliana ABCG transporter genes that satisfied the set criteria: ABCG30, ABCG32, ABCG33, ABCG34, ABCG37, $A B C G 38, A B C G 40, A B C G 41, A B C G 42$, and $A B C G 43$.

We previously analyzed the expression levels of some transporter genes during the TE differentiation of cultured A. thaliana cells. The expression profiles indicated that four ABCG transporter genes ( $A B C G 11, A B C G 22, A B C G 29$, and $A B C G 36$ ) were synchronously expressed with reference genes related to secondary wall formation and lignin synthesis. In the same study, $A B C G 27$ was also highly expressed during lignification, although it was not included in the same cluster as the reference genes. Therefore, $A B C G 11$, $A B C G 22, A B C G 27, A B C G 29$, and $A B C G 36$ were added 
Table 1 ABCG transporter genes selected for expression analyses

\begin{tabular}{ll}
\hline Gene name & Annotation \\
\hline$A B C G 11$ & Cuticular wax export [24, 25] \\
$A B C G 22$ & Stomatal regulation [26] \\
$A B C G 27$ & Unknown \\
$A B C G 29$ & $p$-Coumaryl alcohol transport [4] \\
$A B C G 30$ & Root exudation of phytochemicals [18] \\
$A B C G 32$ & Cuticular formation [9] \\
$A B C G 33$ & Unknown \\
$A B C G 34$ & Camalexin transport [19] \\
$A B C G 36$ & IBA transport [27], pathogen resist- \\
& ance [28], heavy metal transport [29] \\
$A B C G 37$ & Coumarin exudation [20] \\
$A B C G 38$ & Unknown \\
$A B C G 40$ & ABA uptake [30] \\
$A B C G 41$ & Unknown \\
$A B C G 42$ & Unknown \\
$A B C G 43$ & Unknown \\
\hline
\end{tabular}

Table 2 Reference genes related to lignin synthesis and secondary wall formation included in the expression analyses

\begin{tabular}{ll}
\hline Gene name & Function \\
\hline VND6 & $\begin{array}{c}\text { Transcriptional switch for metaxylem differentiation } \\
{[31]}\end{array}$ \\
VND7 & $\begin{array}{c}\text { Transcriptional switch for protoxylem differentiation } \\
{[31]}\end{array}$ \\
MYB46 & Transcription factor for cell wall formation [32] \\
MYB58 & Transcription factor for lignin synthesis [33] \\
C4H & Monolignol biosynthetic enzyme [34] \\
CCR1 & Monolignol biosynthetic enzyme [35] \\
CAD5 & Monolignol biosynthetic enzyme [36] \\
AtPrx25 & Lignin dehydrogenative polymerization enzyme [37] \\
XCP1 & Programmed cell death related gene [38] \\
\hline
\end{tabular}

to the list of target genes for the screening of monolignoltransporter candidates. Among the listed candidates, only $A B C G 29$ has been described as a potential monolignol transporter [4]. Finally, 15 ABC transporter genes were selected as targets in our investigation (Table 1).

\section{Expression pattern analysis}

The expression patterns of 15 genes encoding $\mathrm{ABC}$ transporters were analyzed by real-time PCR. Genes encoding transcription factors for xylem differentiation (VND6 and VND7), secondary cell wall synthesis (MYB46), and monolignol synthesis (MYB58), as well as genes for monolignol synthesis ( $C 4 H, C C R 1$, and $C A D 5)$, lignin polymerization (AtPrx 25), and programmed cell death (XCPI) were chosen as reference genes (Table 2). Lignin accumulation varies in different organs and growth stages. In this study, five plant organs from 4- and 6-week-old A. thaliana plants were examined. Bolting stems were not observed during the first 3 weeks, but $2-4-\mathrm{cm}$ stems were detected at 4 weeks in $A$. thaliana. This stem was expected to be actively lignifying, especially in the conducting tissues. Previous studies showed differences in the lignification level between the tops and bottoms of 6-week-old A. thaliana stems, supporting the differences in the expression levels of genes encoding enzymes related to lignification $[1,20]$. Root tissues are also lignified for conducting water and nutrients extracted from the soil. Parenchyma cells, with limited lignification, are relatively abundant in leaves. For these reasons, the expression levels of transporter and reference genes were determined for the following five plant organs of 4- or 6-week-old plants: upper stem, basal stem, cauline leaf, rosette leaf, and root.

All gene expression data were analyzed, and a heat map was created. The genes were classified into six clusters (Fig. 1, I-VI). The expression patterns were roughly divided into two blocks, with one including clusters I, II, and III, and the other including clusters IV, V, and VI. Eight of nine reference genes were included in the first block (Fig. 1, I-III), suggesting that transporters related to lignification may be included in the first block. Seven reference genes, namely, VND6 and VND7 (xylem formation), MYB46 (transcription factor for cell wall formation), MYB58 (transcription factor for lignification), $C 4 H$ and $C C R 1$ (monolignol synthesis), and $X C P 1$ (programmed cell death), were highly expressed in the upper stem and the roots of 6-week-old A. thaliana plants (Fig. 1, II, III-A). Thus, the cell wall that had formed appeared to be undergoing active lignification in these areas. In addition, $A B C G 29$ and $A B C G 33$ were clustered with $M Y B 46$ and $M Y B 58$ (Fig. 1, II-A). An earlier study suggested that $A B C G 29$ encodes a $p$-coumaryl alcohol transporter [4]. Our previous research also suggested that ABCG29 is a monolignol transporter, because $A B C G 29$ was coordinately expressed with reference genes, such as $M Y B 58$, during the lignification of $A$. thaliana cell cultures. The expression pattern of $A B C G 33$ was very similar to that of $A B C G 29$, suggesting that $A B C G 33$ may also be a potential lignin synthesis-related transporter. Furthermore, $A B C G 30, A B C G 34$, and $A B C G 37$ were synchronously expressed with $A t \operatorname{Prx} 25$ in the roots of 4- and 6-week-old plants (Fig. 1, I-D). The roots of the abcg30 mutant had an increased phenolic content, decreased abundance of sugars, and altered fungal and bacterial community profiles in the surrounding soil, suggesting that ABCG30 is related to the exudation of phytochemicals from the roots [21]. ABCG34 was observed to be polarly localized in the plasma membranes of leaf and root epidermal cells, and may be involved in transporting camalexin, a major phytoalexin, in A. thaliana leaves [22]. An altered root exudate chemical composition in the abcg37 mutant implied that ABCG37 affects the exudation of coumarin, 
Fig. 1 Clustering of gene expression data for each analyzed plant organ. Gene expression levels in different organs were analyzed by real-time PCR. Genes and plant organs were ordered using a clustering program (see "Materials and methods") that grouped those with similar expression patterns (I-VI and A-E, respectively). Each gene is represented by a single row, and each plant organ is represented by a single column. Sample labels presented in black and blue text represent 4- and 6-week-old plants, respectively. Green and red correspond to high and low expression levels, respectively

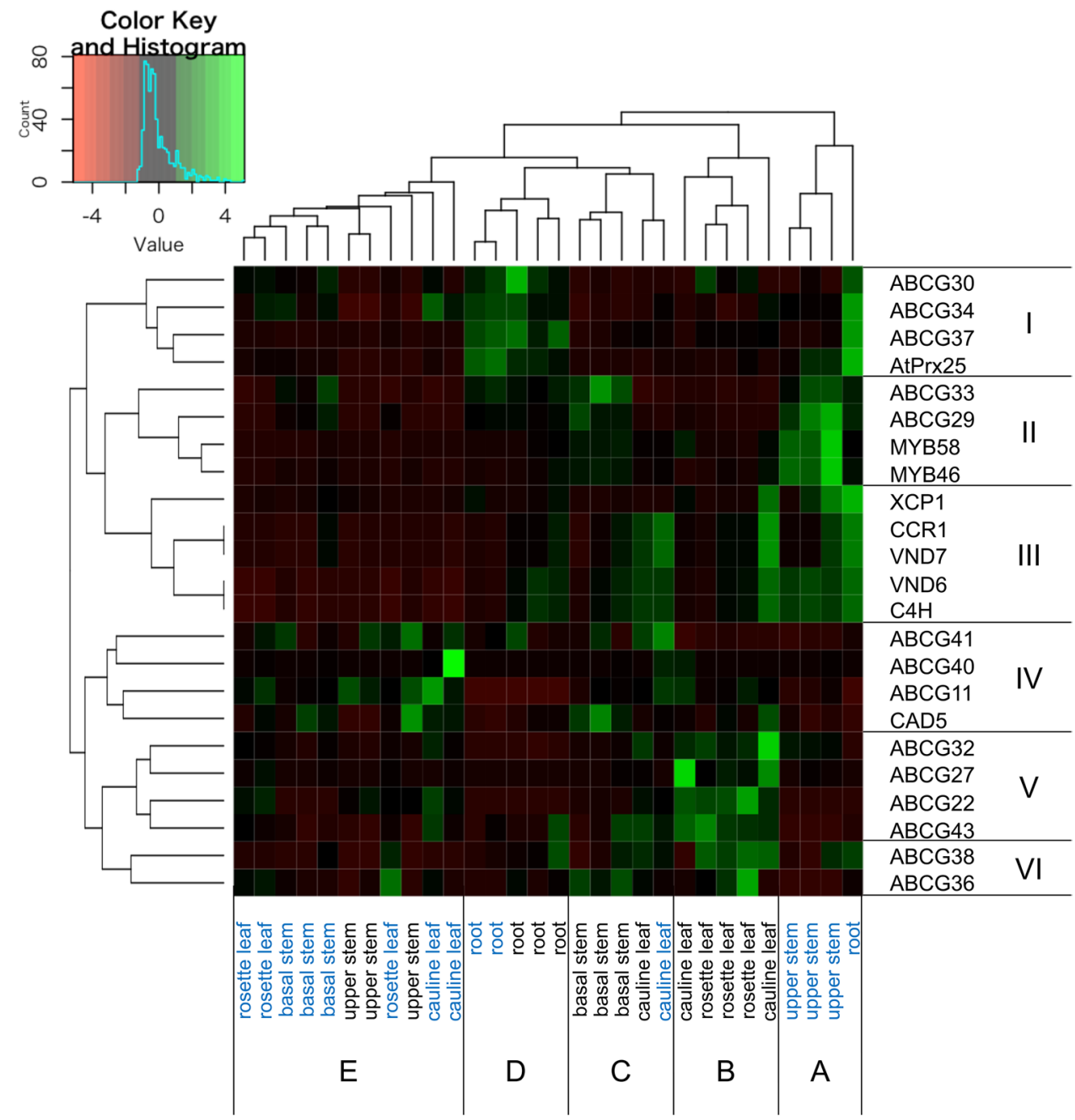

which is a phenylpropanoid compound [23]. The roots of 4- and 6-week-old plants, in which $A B C G 30, A B C G 34$, and $A B C G 37$ were highly expressed, were expected to be actively exuding compounds. The substrates for the transporters encoded by $A B C G 30, A B C G 34$, and $A B C G 37$ have been proposed. However, $\mathrm{ABC}$ transporters can transport several structurally and functionally unrelated substrates [7]. Thus, ABCG30, ABCG34, and ABCG37 may be able to transport other substrates, such as lignin precursors, because the corresponding genes were highly expressed with genes related to lignin synthesis. The expression profiles of candidate genes in different plant tissues were investigated on the Arabidopsis eFP Browser (eFP browser: http://bar.utoronto. ca/efp/cgi-bin/efpWeb.cgi, accessed date March 1, 2018). $A B C G 34$ and $A B C G 37$ were strongly expressed in root at the rosette stage. A co-expression analysis using ATTED-II with both the microarray- and RNA-Seq-based co-expression data (ATTED II: http://atted.jp, accessed date March 1, 2018) showed that $A B C G 34$ and $A B C G 37$ were co-expressed in both databases. Our experimental results were consistent with these results. However, ABCG30 was co-expressed with $A B C G 34$ and $A B C G 37$ based on RNA-Seq data, but the microarray data did not show co-expression. In the coexpression analysis using ATTED-II, ABCG29 co-expressed with the phenylpropanoid biosynthesis genes based on the microarray data but not the RNA-Seq data. Because it was difficult to discuss the expression patterns derived using different databases constructed by the different analytical methods, we used our expression analysis data, which was determined by real-time PCR using gene-specific primers, for the subsequent experiment in this study. Five genes (ABCG29, $A B C G 30, A B C G 33, A B C G 34$, and $A B C G 37$ ) were finally selected as candidate monolignol-transporter genes, because they were synchronously expressed with several reference genes in actively lignifying plant organs.

\section{Semi-quantitative expression levels of candidate genes in single-gene knockout mutants}

We obtained T-DNA insertion mutants for five candidate genes ( $A B C G 29, A B C G 30, A B C G 33, A B C G 34$, and $A B C G 37$ ). Homozygous mutants were selected (see 
Table 3 Relative expression of candidate transporter genes in singleknockout mutants

\begin{tabular}{llllll}
\hline & $A B C G 29$ & $A B C G 30$ & $A B C G 33$ & $A B C G 34$ & $A B C G 37$ \\
\hline WT & $1.0 \pm 0.1$ & VW & $1.0 \pm 0.3$ & $1.0 \pm 0.1$ & $1.0 \pm 0.2$ \\
abcg29 & ND & ND & $1.7 \pm 0.1^{*}$ & $1.5 \pm 0.1$ & $1.3 \pm 0.1$ \\
abcg30 & $1.6 \pm 0.0$ & ND & $2.0 \pm 0.2^{*}$ & $2.2 \pm 0.1^{*}$ & $1.8 \pm 0.3^{*}$ \\
abcg33 & $1.3 \pm 0.4$ & ND & ND & $1.8 \pm 0.7$ & $1.4 \pm 0.3$ \\
abcg34 & $1.8 \pm 0.5$ & S & $1.5 \pm 0.3$ & ND & $1.6 \pm 0.2^{*}$ \\
abcg37 & $0.9 \pm 0.3$ & ND & $1.1 \pm 0.4$ & $0.7 \pm 0.6$ & $\mathrm{ND}$ \\
\hline
\end{tabular}

Gene expression levels in the roots are presented relative to the wildtype expression levels, which were set at 1 . Analyses were conducted with three and five biological replicates for WT, abcg29, abcg30, $a b c g 33$, and $a b c g 34$ and for $a b c g 37$, respectively

$V W$ very week, $N D$ not detected, $S$ strong

*Statistical significance vs the wild-type control in each case $(p<0.05$, Student's $t$ test $)$

"Materials and methods"). The target transcript level in each mutant's root was determined by semi-quantitative reverse transcription PCR. In any mutants, the target transcripts were not amplified (Table 3). We were interested in whether the single-gene knockouts affected the expression levels of the other genes. The candidate gene expression levels in root tissue were also semi-quantified and are presented relative to the wild-type expression levels (Table 3). Because $A B C G 30$ expression was very low in wild-type plants, the relative expression of this gene was evaluated qualitatively (Table 3). The ABCG34 expression level was about twofold higher in $a b c g 30$ plants than in wild-type plants. The ABCG30 expression level was considerably higher in abcg34 plants than in wild-type plants. Thus, the expression levels of $A B C G 30$ and $A B C G 34$ may have affected each other. The $A B C G 37$ expression levels were highly upregulated in the abcg30 and abcg34 mutants. Meanwhile, the expression levels of $A B C G 30$ and $A B C G 34$ were unaffected in the abcg37 mutant. The $A B C G 33$ expression levels were apparently upregulated in $a b c g 29$ and $a b c g 30$ plants, while the expression levels of $A B C G 29$ and $A B C G 30$ were not altered in $a b c g 33$ plants.

\section{Lignin analysis in T-DNA insertion mutants}

The acetyl bromide method revealed that the stem of 6-week-old wild-type $A$. thaliana (Col-0) plants contained approximately $16 \%$ lignin. The lignin contents of singleknockout mutants (abcg29, abcg30, abcg33, and abcg34) were almost the same as the wild-type levels (Table 4). Furthermore, the $\mathrm{S} / \mathrm{G}$ and $\mathrm{H} / \mathrm{G}$ ratios were determined based on the peak areas of pyrolyzed molecules derived from lignin by $\beta-O-4$ cleavage (Online Resource 5 ). The $\mathrm{S} / \mathrm{G}$ and $\mathrm{H} / \mathrm{G}$ ratios were approximately 0.8 and 0.2 , respectively, in wild-type and mutant plants (Table 4). The lignin content
Table 4 Lignin contents and components in single-knockout mutants

\begin{tabular}{lllll}
\hline & Lignin $(\%)$ & & S/G & H/G \\
\hline WT & $16.1 \pm 0.5$ & $(100)$ & $0.80 \pm 0.08$ & $0.18 \pm 0.03$ \\
abcg29 & $16.3 \pm 0.5$ & $(101)$ & $0.71 \pm 0.03$ & $0.19 \pm 0.01$ \\
abcg30 & $16.4 \pm 0.5$ & $(102)$ & $0.76 \pm 0.04$ & $0.19 \pm 0.05$ \\
abcg33 & $16.5 \pm 0.6$ & $(102)$ & $0.67 \pm 0.06$ & $0.19 \pm 0.03$ \\
abcg34 & $15.5 \pm 0.7$ & $(96)$ & $0.64 \pm 0.11$ & $0.22 \pm 0.07$ \\
abcg37 & $19.1 \pm 1.4$ & $(114)$ & $0.80 \pm 0.04$ & $0.18 \pm 0.04$ \\
\hline
\end{tabular}

Lignin contents are presented as the proportion (\%) of the cell wall dry weight. Data in parentheses are presented relative to the wildtype values, which were set at $100 \%$. The pyrolyzed products used for calculating the $\mathrm{S} / \mathrm{G}$ and $\mathrm{H} / \mathrm{G}$ ratios are listed in Online Resource 5. Lignin contents and components were analyzed using four and three independent biological replicates, respectively

of $a b c g 37$ showed an increasing trend, but the reason is not clear. Kaneda et al. [3] stained the transverse sections of inflorescence stems of the T-DNA insertion mutants $a b c g 29$ and $a b c g 33$ with toluidine blue or phloroglucinol. There were no changes in vascular bundle morphology or lignin deposition in the mutant lines compared with wild type. Our results were consistent with their results. No apparent alterations in lignin content or monomer composition were observed, suggesting that individual transporters did not play major roles in the transport of lignin monomers. However, multiple genes may simultaneously contribute to lignin synthesis. In fact, $A B C G 30, A B C G 34$, and $A B C G 37$ were coordinately expressed in the roots of wild-type plants. The encoded proteins may exhibit cooperative metabolic functions. An earlier study indicated that ABCG29 may be a $p$-coumaryl alcohol transporter [4]. The expression of $A B C G 29$ was mainly observed in the primary and secondary roots according to GUS staining. The lower stem and whole vasculature of rosette leaves at 2-3 weeks after bolting also produced GUS signals [4]. Our gene expression data indicated that $A C C G 29$ was highly expressed in the roots, but the highest $A B C G 29$ expression levels were observed in the upper stem of 6-week-old plants. Because Alejandro et al. [4] did not provide expression data for 6-week-old plants, we were unable to compare results at this growth stage. However, we analyzed the lignin contents of single-gene knockout mutants, as did Alejandro et al. [4], who examined root tissues. In contrast, our lignin analysis involved the stem, because stems are generally more lignified than the roots. Alejandro et al. [4] used a thioacidolysis method to confirm that the amounts of all lignin monomers per plant fresh weight were lower in the $a b c g 29$ mutant roots than in the wild-type roots. They also showed that there were no significant differences in the monomer composition between wild-type and $a b c g 29$ mutant plants. In our study, the amount of lignin per cell wall dry weight and the ratios of each monomer were unaffected by single-gene knockouts, 
including abcg29. Our result suggested that ABCG29 is not solely involved in the transport of $p$-coumaryl alcohol, at least in the stem.

\section{Conclusion}

Five transporter genes ( $A B C G 29, A B C G 30, A B C G 33$, $A B C G 34$, and $A B C G 37)$ were selected as candidates, because they were synchronously expressed with the reference genes related to lignin synthesis. The encoded ABC transporters were selected as potential monolignol transporters for further analyses. The expression levels of candidate genes were analyzed in T-DNA insertion mutants. The $A B C G 30$ expression was considerably higher in abcg34 plants than in wild-type plants. $A B C G 34$ expression levels were twofold higher in $a b c g 30$ plants than in wild-type plants. Thus, the expression levels of $A B C G 30$ and $A B C G 34$ may influence each other. An analysis of single-knockout mutants revealed that there were no apparent differences in their lignin contents and monomer compositions, which suggested that individual transporters do not solely contribute to lignin synthesis.

Acknowledgements This work was supported by the Japan Society for the Promotion of Science (JSPS) KAKENHI Scientific Research (B) [Grant number 26292097 (Y.T.)], JSPS KAKENHI Exploratory Research [Grant number 15K14774 (Y.T.)], and JSPS KAKENHI Scientific Research (B) [Grant number 17H03846 (Y.T.)]. We thank Edanz Group (http://www.edanzediting.com/ac) for editing a draft of this manuscript.

\section{References}

1. Ehlting J, Mattheus N, Aeschliman DS, Li E, Hamberger B, Cullis IF, Zhuang J, Kaneda M, Mansfield SD, Samuels L, Ritland K, Ellis BE, Bohlmann J, Douglas CJ (2005) Global transcript profiling of primary stems from Arabidopsis thaliana identifies candidate genes for missing links in lignin biosynthesis and transcriptional regulators of fiber differentiation. Plant J 42:618-640

2. Miao YC, Liu CJ (2010) ATP-binding cassette-like transporters are involved in the transport of lignin precursors across plasma and vacuolar membranes. Proc Natl Acad Sci USA 107:22728-22733

3. Kaneda M, Schuetz M, Lin B, Chanis C, Hamberger B, Western T, Ehlting J, Samuels A (2011) ABC transporters coordinately expressed during lignification of Arabidopsis stems include a set of $\mathrm{ABCB}$ s associated with auxin transport. J Exp Bot 62:2063-2077

4. Alejandro S, Lee Y, Tohge T, Sudre D, Osorio S, Park J, Bovet L, Lee Y, Geldner N, Fernie AR, Martinoia E (2012) AtABCG29 is a monolignol transporter involved in lignin biosynthesis. Curr Biol 22:1207-1212

5. Henikoff S, Greene EA, Pietrokovski S, Bork P, Attwood TK, Hood L (1997) Gene families: the taxonomy of protein paralogs and chimeras. Science 278:609-614

6. Kos V, Ford RC (2009) The ATP-binding cassette family: a structural perspective. Cell Mol Life Sci 66:3111-3126
7. Hwang JU, Song WY, Hong D, Ko D, Yamaoka Y, Jang S, Yim S, Lee E, Khare D, Kim K, Palmgren M, Yoon HS, Martinoia E, Lee Y (2016) Plant ABC transporters enable many unique aspects of a terrestrial plant's lifestyle. Mol Plant 9:338-355

8. Verrier PJ, Bird D, Burla B, Dassa E, Forestier C, Geisler M, Klein M, Kolukisaoglu Ü, Lee Y, Martinoia E, Murphy A, Rea PA, Samuels L, Schulz B, Spalding EJ, Yazaki K, Theodoulou FL (2008) Plant ABC proteins: a unified nomenclature and updated inventory. Trends Plant Sci 13:151-159

9. Cock JM, Sterck L, Rouze P, Scornet D, Allen AE, Amoutzias G, Anthouard V, Artiguenave F, Aury JM, Badger JH, Beszteri B, Billiau K, Bonnet E, Bothwell JH, Bowler C, Boyen C, Brownlee C, Carrano CJ, Charrier B, Cho GY, Coelho SM, Collen J, Corre E, Da Silva C, Delage L, Delaroque N, Dittami SM, Doulbeau S, Elias M, Farnham G, Gachon CMM, Gschloessl B, Heesch S, Jabbari K, Jubin C, Kawai H, Kimura K, Kloareg B, Kupper FC, Lang D, Le Bail A, Leblanc C, Lerouge P, Lohr M, Lopez PJ, Martens C, Maumus F, Michel G, Miranda-Saavedra D, Morales J, Moreau H, Motomura T, Nagasato C, Napoli CA, Nelson DR, Nyvall-Collen P, Peters AF, Pommier C, Potin P, Poulain J, Quesneville H, Read B, Rensing SA, Ritter A, Rousvoal S, Samanta M, Samson G, Schroeder DC, Segurens B, Strittmatter M, Tonon T, Tregear JW, Valentin K, von Dassow P, Yamagishi T, Van de Peer Y, Wincker P (2010) The Ectocarpus genome and the independent evolution of multicellularity in brown algae. Nature 465:617-621

10. Tyler BM, Tripathy S, Zhang X, Dehal P, Jiang RHY, Aerts A, Arredondo FD, Baxter L, Bensasson D, Beynon JL, Chapman J, Damasceno CMB, Dorrance AE, Dou D, Dickerman AW, Dubchak IL, Garbelotto M, Gijzen M, Gordon SG, Govers F, Grunwald NJ, Huang W, Ivors KL, Jones RW, Kamoun S, Krampis K, Lamour KH, Lee MK, McDonald WH, Medina M, Meijer HJG, Nordberg EK, Maclean DJ, Ospina-Giraldo MD, Morris PF, Phuntumart V, Putnam NH, Rash S, Rose JKC, Sakihama Y, Salamov AA, Savidor A, Scheuring CF, Smith BM, Sobral BWS, Terry A, Torto-Alalibo TA, Win J, Xu Z, Zhang H, Grigoriev IV, Rokhsar DS, Boore JL (2006) Phytophthora genome sequences uncover evolutionary origins and mechanisms of pathogenesis. Science 313:1261-1266

11. Anjard C, Loomis WF (2002) Evolutionary analyses of ABC transporters of Dictyostelium discoideum. Eukaryot Cell $1: 643-652$

12. Campbell EJ, Schenk PM, Kazan K, Penninckx IAMA., Anderson JP, Maclean DJ, Cammue B, Ebert PR, Manners JM (2003) Pathogen-responsive expression of a putative ATP-binding cassette transporter gene conferring resistance to the diterpenoid sclareol is regulated by multiple defense signaling pathways in Arabidopsis. Plant Physiol 133:1272-1284

13. Bessire M, Borel S, Fabre G, Carraça L, Efremova N, Yephremov A, Cao Y, Jetter R, Jacquat AC, Métraux JP, Nawrath C (2011) A member of the PLEIOTROPIC DRUG RESISTANCE family of ATP binding cassette transporters is required for the formation of a functional cuticle in Arabidopsis. Plant Cell 23:1958-1970

14. Van Acker R, Vanholme R, Storme V, Mortimer JC, Dupree P, Boerjan W (2013) Lignin biosynthesis perturbations affect secondary cell wall composition and saccharification yield in Arabidopsis thaliana. Biotechnol Biofuels. https://doi. org/10.1186/1754-6834-6-46

15. Espiñeira JM, Novo Uzal E, Gómez Ros LV, Carrión JS, Merino F, Ros Barceló A, Pomar F (2011) Distribution of lignin monomers and the evolution of lignification among lower plants. Plant Biol 13:59-68

16. Takeuchi M, Kegasa T, Watanabe A, Tamura M, Tsutsumi Y (2017) Expression analysis of transporter genes for screening candidate monolignol transporters using Arabidopsis thaliana cell suspensions during tracheary element differentiation. J Plant Res 131:297-305 
17. Johnson DB, Moore WE, Zank LC (1961) The spectrometric determination of lignin in small wood samples. Tappi 44:793-798

18. Kuroda KI, Nishimura N, Izumi A, Dimmel DR (2002) Pyrolysis of lignin in the presence of tetramethylammonium hydroxide: a convenient method for $S / G$ ratio determination. J Agric Food Chem 50:1022-1027

19. Rensing SA, Lang D, Zimmer AD, Terry A, Salamov A, Shapiro H, Nishiyama T, Perroud PF, Lindquist EA, Kamisugi Y, Tanahashi T, Sakakibara K, Fujita T, Oishi K, Shin-I T, Kuroki Y, Toyoda A, Suzuki Y, Hashimoto S, Yamaguchi K, Sugano S, Kohara Y, Fujiyama A, Anterola A, Aoki S, Ashton N, Barbazuk WB, Barker E, Bennetzen JL, Blankenship R, Cho SH, Dutcher SK, Estelle M, Fawcett JA, Gundlach H, Hanada K, Heyl A, Hicks KA, Hughes J, Lohr M, Mayer K, Melkozernov A, Murata T, Nelson DR, Pils B, Prigge M, Reiss B, Renner T, Rombauts S, Rushton PJ, Sanderfoot A, Schween G, Shiu SH, Stueber K, Theodoulou FL, Tu H, Van de Peer Y, Verrier PJ, Waters E, Wood A, Yang L, Cove D, Cuming AC, Hasebe M, Lucas S, Mishler BD, Reski R, Grigoriev IV, Quatrano RS, Boore JL (2008) The Physcomitrella genome reveals evolutionary insights into the conquest of land by plants. Science 319:64-69

20. Pandey JL, Kiemle SN, Richard TL, Zhu Y, Cosgrove DJ, Anderson CT (2016) Investigating biochemical and developmental dependencies of lignification with a click-compatible monolignol analog in Arabidopsis thaliana stems. Front Plant Sci 7:1-15

21. Badri DV, Quintana N, El Kassis EG, Kim HK, Choi YH, Sugiyama A, Verpoorte R, Martinoia E, Manter DK, Vivanco JM (2009) An ABC transporter mutation alters root exudation of phytochemicals that provoke an overhaul of natural soil microbiota. Plant Physiol 151:2006-2017

22. Khare D, Choi H, Huh SU, Bassin B, Kim J, Martinoia E, Sohn KH, Paek KH, Lee Y (2017) Arabidopsis ABCG34 contributes to defense against necrotrophic pathogens by mediating the secretion of camalexin. Proc Natl Acad Sci 114:E5712-E5720

23. Ziegler J, Schmidt S, Strehmel N, Scheel D, Abel S (2017) Arabidopsis transporter ABCG37/PDR9 contributes primarily highly oxygenated coumarins to root exudation. Sci Rep. https://doi. org/10.1038/s41598-017-03250-6

24. Bird D, Beisson F, Brigham A, Shin J, Greer S, Jetter R, Kunst L, Wu X, Yephremov A, Samuels L (2007) Characterization of Arabidopsis ABCG11/WBC11, an ATP binding cassette (ABC) transporter that is required for cuticular lipid secretion. Plant $\mathrm{J}$ 52:485-498

25. Panikashvili D, Savaldi-Goldstein S, Mandel T, Yifhar T, Franke RB, Hofer R, Schreiber L, Chory J, Aharoni A (2007) The Arabidopsis DESPERADO/AtWBC11 transporter is required for cutin and wax secretion. Plant Physiol 145:1345-1360

26. Kuromori T, Sugimoto E, Shinozaki K (2011) Arabidopsis mutants of AtABCG22, an ABC transporter gene, increase water transpiration and drought susceptibility. Plant J 67:885-894
27. Strader LC, Bartel B (2009) The Arabidopsis PLEIOTROPIC DRUG RESISTANCE8/ABCG36 ATP binding cassette transporter modulates sensitivity to the auxin precursor indole-3-butyric acid. Plant Cell 21:1992-2007

28. Campe R, Langenbach C, Leissing F, Popescu GV, Popescu SC, Goellner K, Beckers GJM, Conrath U (2016) ABC transporter PEN3/PDR8/ABCG36 interacts with calmodulin that, like PEN3, is required for Arabidopsis nonhost resistance. New Phytol 209:294-306

29. Kim DY, Bovet L, Maeshima M, Martinoia E, Lee Y (2007) The ABC transporter AtPDR8 is a cadmium extrusion pump conferring heavy metal resistance. Plant J 50:207-218

30. Kang J, Hwang JU, Lee M, Kim YY, Assmann SM, Martinoia E, Lee Y (2010) PDR-type ABC transporter mediates cellular uptake of the phytohormone abscisic acid. Proc Natl Acad Sci 107:2355-2360

31. Kubo M, Udagawa M, Nishikubo N, Horiguchi G, Yamaguchi M, Ito J, Mimura T, Fukuda H, Demura T (2005) Transcription switches for protoxylem and metaxylem vessel formation. Genes Dev 19:1855-1860

32. Zhong R, Richardson EA, Ye Z (2007) The MYB46 transcription factor is a direct target of SND1 and regulates secondary wall biosynthesis in Arabidopsis. Plant Cell 19:2776-2792

33. Zhou J, Lee C, Zhong R, Ye ZH (2009) MYB58 and MYB63 are transcriptional activators of the lignin biosynthetic pathway during secondary cell wall formation in Arabidopsis. Plant Cell $21: 248-266$

34. Schilmiller AL, Stout J, Weng JK, Humphreys J, Ruegger MO, Chapple C (2009) Mutations in the cinnamate 4-hydroxylase gene impact metabolism, growth and development in Arabidopsis. Plant J 60:771-782

35. Ruel K, Berrio-Sierra J, Mir-Derikvand M, Pollet B, Thévenin J, Lapierre C, Jouanin L, Joseleau JP (2009) Impact of CCR1 silencing on the assembly of lignified secondary walls in Arabidopsis thaliana. New Phytol 184:99-113

36. Sibout R, Eudes A, Mouille G, Pollet B, Lapierre C, Jouanin L, Séguin A (2005) CINNAMYL ALCOHOL DEHYDROGENASE$\mathrm{C}$ and $-\mathrm{D}$ are the primary genes involved in lignin biosynthesis in the floral stem of Arabidopsis. Plant Cell 17:2059-2076

37. Shigeto J, Itoh Y, Hirao S, Ohira K, Fujita K, Tsutsumi Y (2015) Simultaneously disrupting AtPrx2, AtPrx 25 and AtPrx 71 alters lignin content and structure in Arabidopsis stem. J Integr Plant Biol 57:349-356

38. Funk V, Kositsup B, Zhao C, Beers EP (2002) The Arabidopsis xylem peptidase XCP1 is a tracheary element vacuolar protein that may be a papain ortholog. Plant Physiol 128:84-94 